\title{
Marketing Management in the Hotel Industry: A Systematic Literature Review by Using Text Mining
}

\author{
Jeou-Shyan Horng ${ }^{1} \oplus$, Chih-Hsing Liu ${ }^{2}$, Sheng-Fang Chou ${ }^{3}$, Tai-Yi Yu ${ }^{4}$ and Da-Chian $\mathrm{Hu}^{1, *}$ \\ 1 Department of Food and Beverage, Shih Chien University, Taipei 104336, Taiwan; t10004@ntnu.edu.tw \\ 2 Department of Tourism Management, National Kaohsiung University of Science and Technology, \\ Kaohsiung 811532, Taiwan; phd20110909@gmail.com \\ 3 Department of Hospitality Management, Ming Chuan University, Taoyuan 333321, Taiwan; \\ dodo.chou@gmail.com \\ 4 Department of Risk Management and Insurance, Ming Chuan University, Taipei 111005, Taiwan; \\ yti@mail.mcu.edu.tw \\ * Correspondence: 894560241@gms.tku.edu.tw
}

Citation: Horng, J.-S.; Liu, C.-H.; Chou, S.-F.; Yu, T.-Y.; Hu, D.-C. Marketing Management in the Hotel Industry: A Systematic Literature Review by Using Text Mining. Sustainability 2022, 14, 2344. https:// doi.org/10.3390/su14042344

Academic Editors: Andrea Pérez and Tomás F. Espino-Rodríguez

Received: 26 November 2021 Accepted: 14 February 2022 Published: 18 February 2022

Publisher's Note: MDPI stays neutral with regard to jurisdictional claims in published maps and institutional affiliations.

Copyright: (C) 2022 by the authors. Licensee MDPI, Basel, Switzerland. This article is an open access article distributed under the terms and conditions of the Creative Commons Attribution (CC BY) license (https:// creativecommons.org/licenses/by/ $4.0 /)$.

\begin{abstract}
The current research is a systematic review of the literature on hotel marketing management that provides evidence that hotel marketing management contributes to organizational performance and satisfaction, and provides insights into how hotel operators can successfully implement it. This systematic review of the literature is based on the analysis of 417 papers via a text-mining methodology. Through cluster analysis, we divided the literature on hotel marketing management into four clusters, namely, literature regarding marketing reviews and frameworks, marketing strategies, services, and customers. These results pointed to some potential directions for future research in each cluster. This research can benefit researchers studying the current topics in the hotel marketing management field and help them recognize potential research areas. Additionally, it enables hoteliers to understand the benefits and processes of hotel marketing and defines the key elements of implementing a successful marketing campaign.
\end{abstract}

Keywords: marketing management; hotel industry; systematic review; text mining

\section{Introduction}

Due to the continuous evolution of marketing theory in the hotel industry during the past decade, more and more relevant studies have been conducted. Whether they are related to theoretical innovation or the evolution of marketing tools, the hotel industry has made many changes in terms of marketing. However, there have been many relevant studies on hotel marketing, and the related knowledge system is still fragmented. To understand the knowledge context of hotel marketing, past studies have tried to review the relevant literature from different perspectives. A previous review by Bowen and Sparks [1] focused on hospitality marketing and reviewed eight major journals from 1990 to 1997 and provided future research directions. Oh [2] reviewed the development of hotel and tourism marketing research in eight journals from 2002 to 2003 and provided future research directions. Svensson et al. [3] selected six journals in the field of tourism and hospitality based on journal rankings and reviewed the empirical characteristics from 2000 to 2007. Dev et al. [4] reviewed the research on hospitality marketing published in Cornell Hospitality Quarterly over the past 50 years and used citation analysis to find the most influential articles published in Cornell Hospitality Quarterly every 10 years. They found that during the 2010s, the changes introduced by electronic media continued, the most notable of which was the decline of printed media and the rise of social media. Yoo et al. [5] examined the progress of hotel marketing research in terms of subject areas, industry applications, and methodologies over the past decade, and they identified significant trends in hotel marketing research. 
To date, the previous literature in hotel marketing highlights the contribution of future directions [2] and finds the most influential articles in specific journals [4]. However, there are still research gaps to be addressed. First, most studies were from before 2015 and few review articles on hotel marketing have been published during recent years [1-3], especially regarding the marketing tools that have undergone tremendous changes. For example, data-oriented marketing [6], digital marketing [7,8], social media marketing [9], online celebrity marketing [10], and sustainable marketing [11,12] have all emerged recently. It is necessary to conduct a comprehensive review of the development trends and marketing tools in hotel marketing in recent years. Second, although past studies of hotel marketing have focused on hospitality journals, the number of journals and articles used was low, which led to undergeneralized findings and misleading outputs [1,2]. This research reviews 27 tourism and hospitality journals included in the Web of Science (WOS) database from 2010 to 2020; these journals contain 4000 articles. Compared with previous related studies, this research is superior to past research in terms of the number of articles included and the year of publication. Furthermore, in the highly competitive environment of the hotel industry, discovering the context and trends in the relevant literature is of great help to researchers and practitioners. Third, bibliometrics were mostly used in the previous review articles. This research uses text mining to conduct literature analysis. Using text mining and topic modeling, this study extracts concepts and dimensions from a large set of articles automatically and systematically. This analysis method is particularly suitable for finding unbiased and content-oriented patterns in complex situations.

Most of the previous studies in this field only described the development of hotel marketing or focused on specific topics, and they failed to develop a comprehensive framework for hotel industry marketing. Furthermore, few review articles on hotel marketing have been published in recent years, especially regarding the marketing tools that have undergone tremendous changes. For example, data-oriented marketing, digital marketing, social marketing, and online celebrity marketing have all emerged recently. Therefore, it is necessary to develop a framework that can be used by hotel practitioners for marketing in the future. In addition, for academics, reviewing the literature can also reveal the current trends in hotel marketing and thus provide directions for future empirical research.

The previous review articles on hotel marketing were mostly published before 2015, and there are less than 200 of them. This research reviews 27 tourism and hospitality journals included in the Web of Science (WOS) database from 2010 to 2020; these journals contain 4000 articles. Compared with previous related studies, this research is superior to the past in terms of the number of articles included and the year of publication. Furthermore, in the highly competitive environment of the hotel industry, discovering the context and trends in the relevant literature is of great help to researchers and practitioners.

In terms of analysis tools, bibliometrics were mostly used in the previous review articles. This research uses text mining to conduct a literature analysis. Using text mining and topic modeling, this study extracts concepts and dimensions from a large set of articles automatically and systematically. This analysis method is particularly suitable for finding unbiased and content-oriented patterns in complex situations [13].

In view of the above information, a broader stance needs to be taken when examining this topic. The purpose of this study is to provide a comprehensive overview of the literature on hotel marketing management. Moreover, this study aims to illustrate the abovementioned perspective regarding hotel marketing management. Through the research in this literature review, companies can better understand how to achieve organizational goals through hotel marketing management. In addition, researchers can consider the results of this study to identify future research trends in hotel marketing management. Finally, this study utilizes text mining, which allows for higher reliability and validity of the results $[14,15]$. 


\section{Theoretical Background}

Research on a given topic over time through incremental learning is the cornerstone for future research directions [16]. A specific topic usually needs a clear definition to avoid any confusing interpretation. In marketing management, in response to the recent changes in the industrial environment and consumer preferences, marketing strategies and marketing tools have evolved. According to Kolter's definition, while Marketing 1.0 is based on product features, the core of Marketing 2.0 is customer satisfaction. and Marketing 3.0 is based on product features and customer satisfaction with the addition of people. Due to this added value, companies that successfully achieve Marketing 3.0 usually attract a group of fans. The most important aspect of Marketing 4.0 is how the development of digital innovations has changed marketing. The superstructure that originally controlled part of a firm's resources in the past has gradually been diluted by more horizontal power. In this world, when the power of a community surpasses that of individuals, customers become stronger, and they are more vocal and unafraid of large companies or brands; additionally, they love to share everything, whether good or bad. Social circles become the main source of influence, and they are far better than external marketing communication methods. Therefore, new marketing models such as word-of-mouth marketing [17-20], social media marketing [21-24], online celebrity marketing [25], and experience marketing [26-29] have emerged.

The sources of big data are many faceted, including mobile transactions, internet traffic (e.g., clickstreams), social media, and user-generated content. These data are recorded on purpose through sensors and transaction records [30]. The purpose of big data analysis is to generate new insights that can meaningfully make up for the shortcomings of traditional statistical data, surveys, and archive data sources, and they are in real time. The use of Google search queries to detect social epidemics is a classic example of the application of big data analytics [31]. As demonstrated by Boyd and Crawford [32], big data analysis redefines the composition of knowledge, leading to changes in epistemology. Thus, rather than being viewed as a uniform method, big data analysis can be regarded as a new research paradigm that uses a variety of analytical tools and makes inferences about reality from large amounts of data. Although big data analysis cannot be used for hypothesis verification, it is possible to explore new models or predict future trends by analyzing data [33]. Although big data is regarded as a new method of knowledge creation, the problems that may produce spurious correlations cannot be ignored. Therefore, scholars calling for the adoption of big data methods must also rely on theory [32].

\section{Methodology}

Literature review research has three elements: developing methods in a systematic way, providing detailed analysis procedures, and ensuring comprehensiveness by providing a spectrum of relevant research. In this way, other scholars can use the same method to replicate a given study [34].

According to Tranfield et al. [35], we identified published studies on hotel marketing management. There are three steps in this process: planning the review, conducting the review, and reporting and disseminating the results. These steps have been used in many review articles $[36,37]$. Figure 1 shows the research process. 


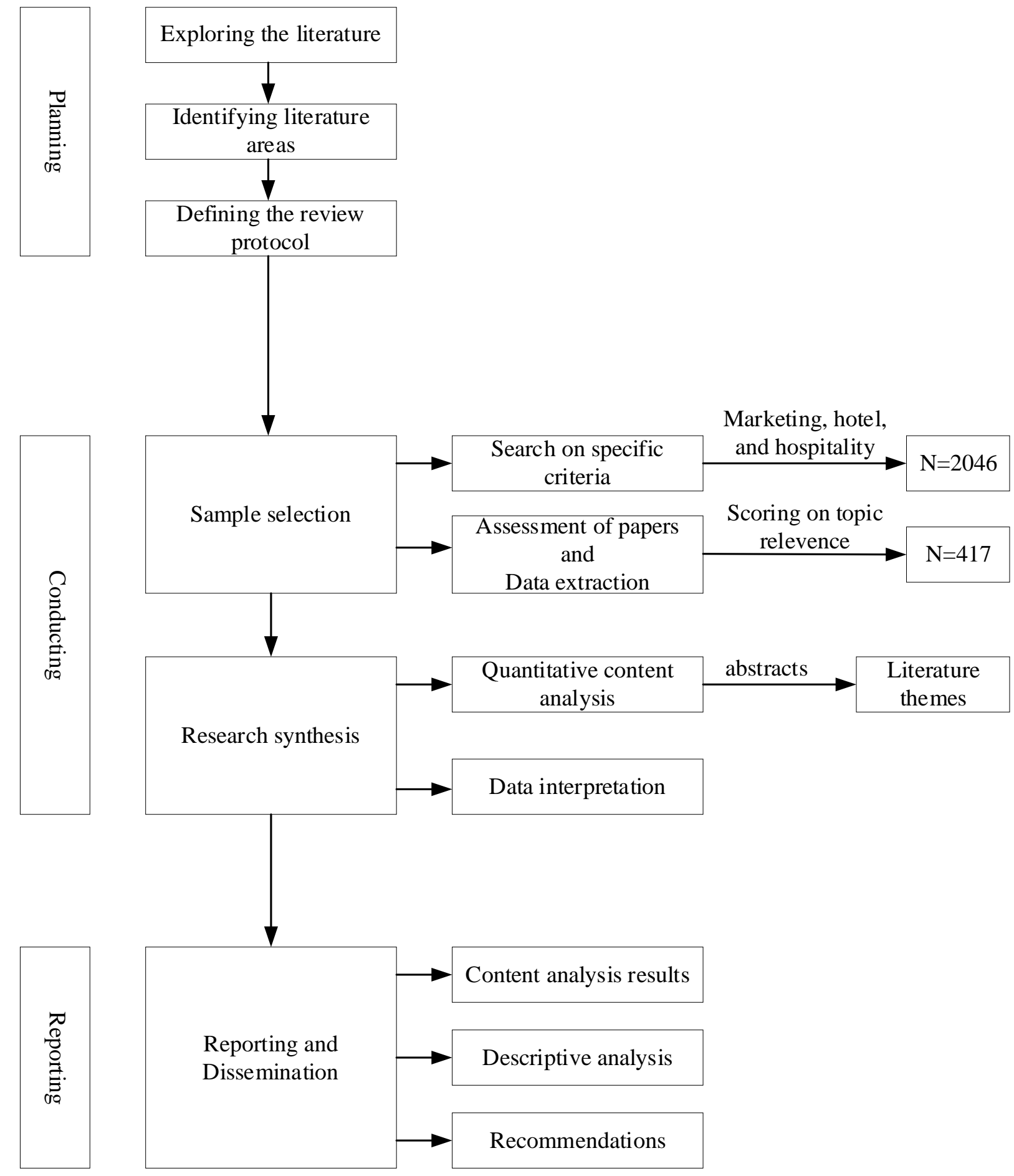

Figure 1. Steps of the literature review process.

\subsection{Planning the Review}

During the planning stage, the subjects in the literature were examined at a high level for meaningful operational definitions and the main concepts related to the hospitality field. This stage of the process was repeated until the results reached convergence. 


\subsection{Conducting the Review}

The tasks related to conducting the review included a literature search to evaluate and extract the most relevant articles for synthesizing the research framework [35]. This stage can be subdivided into the following stages.

\subsection{Sample Selection}

We began to collect documents from the Web of Science database (WoS) in October 2020. The criteria that we used are as follows: The article needed to have been published in English, the article needed to have gone through a peer review process, and the research domain was limited to tourism and hospitality. A total of 4000 research articles were collected. In the second step, we employed the abstracts of the documents as our screening criteria. We only selected articles that mentioned marketing, hotels, and hospitality in the abstract. There were 417 studies left at this stage, which is the total number of articles that were analyzed through text mining.

\subsection{Research Synthesis}

This stage integrated the word segmentation results from our examination of the abstracts into possible topics. In this stage, we mainly used the quantitative content analysis method (QCA) for text exploration [38]. The employed research tool uses Python. The advantage of using Python is that there are ready-made kits that provide the relevant quantitative indicators and allow us to verify the quality of our results and replicability of our findings. Since there are other machine learning packages for Python, we could further analyze our results and present them visually.

In the first step of text mining, we excluded stop words, punctuation marks, and other meaningless symbols, as well as common roots and high-frequency words such as "this", "is", "research", "paper", and "analysis". Text mining provides a quick, labor-saving, and accurate way to extract the keywords from the topics of all the documents; however, the disadvantage of this method is that we could not perform further classification. Therefore, after completing the word segmentation and term frequency matrix, we presented and explained the results through a cluster analysis and our judgment of industry domain knowledge and expert experience.

Agrawal et al. [39] pointed out that finding association rules is an important datamining subject, and there have been quite a few studies using association rules to solve data-mining problems. An association rule is mainly used to determine the relationship between items or features in the database. For example, in the shopping process, if you buy item $X$ and also buy item $Y$, there is a relationship between the two items. It is useful for decision-makers to have this information. Therefore, analyzing random data and finding out the synchronization relationship is the purpose of the association rule algorithm. In this study, the following association rules were defined [40].

\subsection{Reporting and Dissemination}

The third step used descriptive statistics to present different views and topics in the literature. Figure 2 focuses on the mainstream research presented in the field of hotel marketing management from 2010 to 2020. 


\section{Number of Publications}

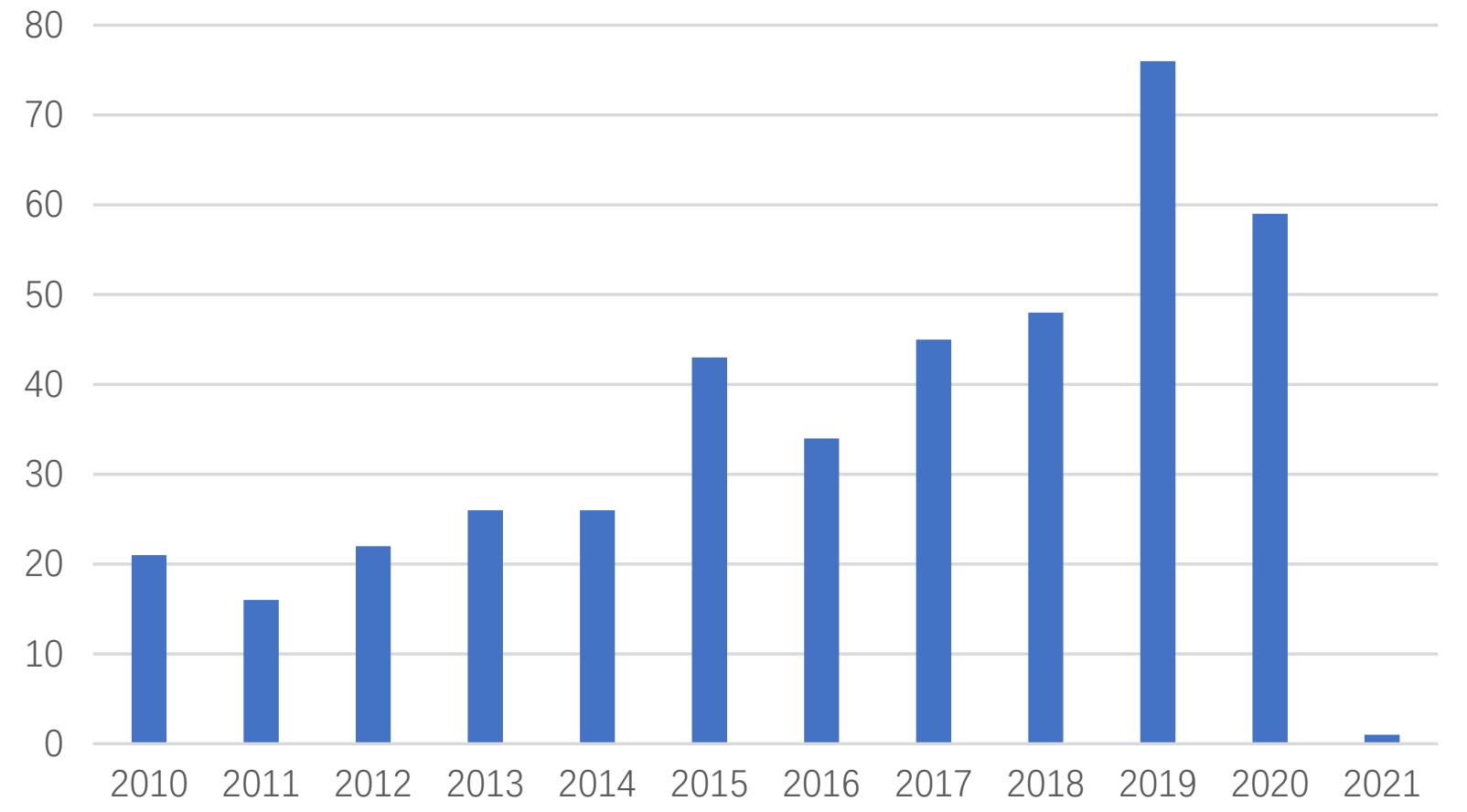

Figure 2. Number of publications per year.

\section{Findings}

This study used QCA to identify the most frequent terms in the literature. The frequencies and percentage of terms that appeared in the articles are shown in Table 1, and the Term Frequency-Inverse Document Frequency (TF-IDF) was used to identify the words that occurred the most frequently and that were relevant to the context [41]. As expected, "hospitality" and "tourism" were among the most frequently occurring terms. Surprisingly, "brand" and "experience" were among the top 10 most frequently occurring terms, which shows the high level of academic interest in brand management and experience marketing in the hotel industry [26]. The term frequency list also revealed that social media marketing is a mainstream marketing tool in the hotel industry [42]. In terms of the measurement of marketing performance, service quality, loyalty, and satisfaction were still the critical indicators used in most studies [43].

In this study, the top 50 TF-IDF weighted terms were subjected to a two-stage cluster residual analysis (Figure 3). After a hierarchical cluster analysis method was applied, the number of clusters was two, three, and four, and the total residuals decreased by $9 \%, 5 \%$, and $4.6 \%$, respectively. When the number of clusters was five, the total residual error decreased by $2 \%$. For the top 50 terms, the average interpretation degree of each variable was $4.6 \%$. Therefore, by increasing the number of clusters from four to five, the degree of explanation increased by less than $4.6 \%$. Therefore, we believe that the number of clusters can be set to four while performing the second stage of cluster analysis with the K-means approach. Therefore, during the second stage of cluster analysis, the number of clusters was directly set to four, and K-means cluster analysis was performed. 
Table 1. Most frequent terms in the literature.

\begin{tabular}{|c|c|c|c|}
\hline & No. Cases & $\%$ Cases & TF-IDF \\
\hline hospitality & 249 & $0 \%$ & 49.65 \\
\hline tourism & 138 & $0 \%$ & 46.74 \\
\hline service & 134 & $0 \%$ & 39.13 \\
\hline consumer & 106 & $0 \%$ & 34.89 \\
\hline strategy & 143 & $0 \%$ & 28.15 \\
\hline management & 121 & $0 \%$ & 30.89 \\
\hline brand & 65 & $0 \%$ & 28.46 \\
\hline intention & 77 & $0 \%$ & 26.75 \\
\hline performance & 64 & $0 \%$ & 28.71 \\
\hline experience & 75 & $0 \%$ & 26.06 \\
\hline tourist & 61 & $0 \%$ & 24.28 \\
\hline behavior & 75 & $0 \%$ & 22.37 \\
\hline social_media & 46 & $0 \%$ & 23.69 \\
\hline quality & 62 & $0 \%$ & 21.97 \\
\hline market & 69 & $0 \%$ & 21.28 \\
\hline perceived & 66 & $0 \%$ & 19.11 \\
\hline managers & 77 & $0 \%$ & 17.48 \\
\hline loyalty & 38 & $0 \%$ & 18.04 \\
\hline destination & 46 & $0 \%$ & 17.89 \\
\hline environment & 52 & $0 \%$ & 16.75 \\
\hline marketing_strategy & 70 & $0 \%$ & 15.38 \\
\hline satisfaction & 49 & $0 \%$ & 17.18 \\
\hline empirical & 73 & $0 \%$ & 13.82 \\
\hline price & 35 & $0 \%$ & 14.47 \\
\hline product & 50 & $0 \%$ & 13.30 \\
\hline communication & 42 & $0 \%$ & 13.07 \\
\hline framework & 48 & $0 \%$ & 12.95 \\
\hline perceptions & 45 & $0 \%$ & 11.67 \\
\hline benefit & 43 & $0 \%$ & 11.31 \\
\hline effectiveness & 30 & $0 \%$ & 11.24 \\
\hline revenue & 28 & $0 \%$ & 12.22 \\
\hline process & 43 & $0 \%$ & 10.65 \\
\hline international & 38 & $0 \%$ & 11.17 \\
\hline attributes & 31 & $0 \%$ & 10.12 \\
\hline food & 25 & $0 \%$ & 10.54 \\
\hline website & 21 & $0 \%$ & 11.24 \\
\hline innovation & 21 & $0 \%$ & 10.40 \\
\hline trust & 25 & $0 \%$ & 10.22 \\
\hline online_review & 21 & $0 \%$ & 10.60 \\
\hline employees & 28 & $0 \%$ & 10.26 \\
\hline characteristics & 42 & $0 \%$ & 10.15 \\
\hline accommodation & 24 & $0 \%$ & 10.62 \\
\hline decision & 26 & $0 \%$ & 9.71 \\
\hline knowledge & 36 & $0 \%$ & 9.58 \\
\hline internet & 24 & $0 \%$ & 9.01 \\
\hline interviews & 30 & $0 \%$ & 9.56 \\
\hline advertising & 22 & $0 \%$ & 8.36 \\
\hline segments & 26 & $0 \%$ & 9.14 \\
\hline engagement & 20 & $0 \%$ & 9.34 \\
\hline attitudes & 25 & $0 \%$ & 8.51 \\
\hline
\end{tabular}




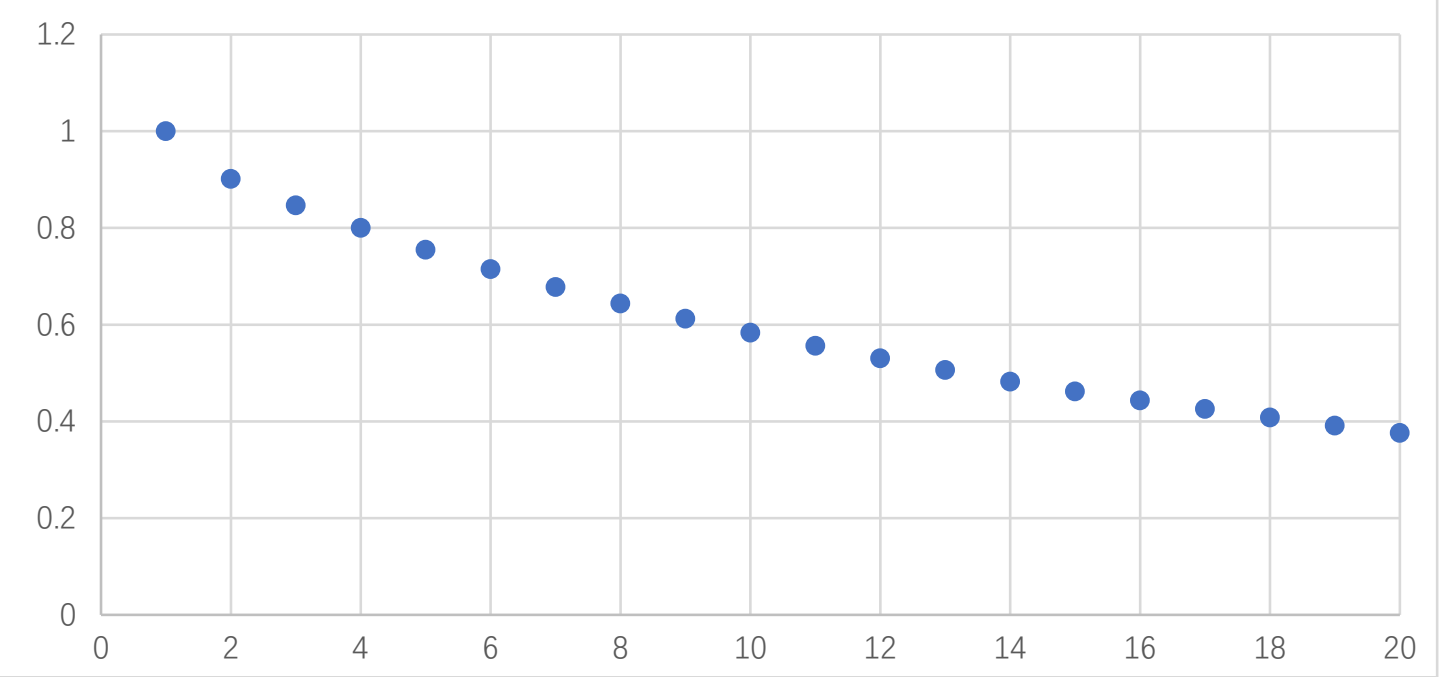

Figure 3. The relationship between the ratio of the cumulative number of words and the cumulative word frequency ratio.

After the cluster analysis was used to divide the terms into four clusters, each cluster was listed according to the TF-IDF weights of its terms. In Table 2, we show the number of words with high TF-IDF weights as well as the number of articles and their proportions in each cluster. We also used word clouds to visualize the results of each group, which are given in Figures 4-7. Figures 8-11 showed the relationship between keywords, the thicker the path, the stronger the relationship between the two keywords. The larger a word in a word cloud is, the higher the weight of the TF-IDF of that word. For cluster 1, the number of articles was 98 , representing $23.5 \%$ of all the articles. The words with the highest TF-IDF weights that appeared in this cluster included "tourism", "hospitality", "management", "tourist", and "destination", in that order. There were 122 articles in cluster 2, accounting for $29.25 \%$ of the articles examined. The words with high TF-IDF weights that appeared in this cluster included "strategy", "tourist", "experience", "market", and "hospitality". In cluster 3, there were 104 articles, accounting for $24.94 \%$ of all the articles. In cluster 3, the terms "service", "performance", "hospitality", and "management" had the highest TF-IDF weights. Cluster 4 had 94 articles, accounting for $22.54 \%$ of all the articles. The words with high TF-IDF weights in cluster 4 were "consumer", "brand", "intention", and "behavior".

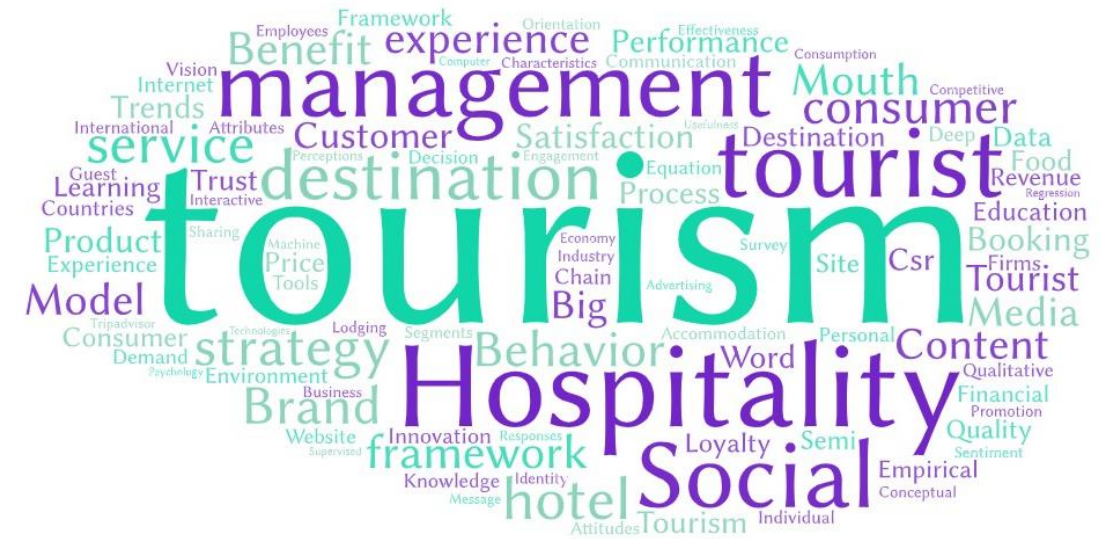

Figure 4. Word cloud for cluster 1. 
Table 2. Terms with high TF-IDF in the clusters.

\begin{tabular}{|c|c|c|}
\hline Cluster & Terms with High TF-IDF & Percentage of Articles (\%) \\
\hline 1 & $\begin{array}{l}\text { tourism, hospitality, } \\
\text { management, tourist, } \\
\text { destination, strategy, } \\
\text { experience, framework, } \\
\text { consumer, service, } \\
\text { environment, market }\end{array}$ & $98(23.50 \%)$ \\
\hline 2 & $\begin{array}{l}\text { strategy, tourist, experience, } \\
\text { market, hospitality, } \\
\text { social_media, perceived, } \\
\text { loyalty, price, } \\
\text { marketing_strategy, } \\
\text { environment, effectiveness }\end{array}$ & $122(29.25 \%)$ \\
\hline 3 & $\begin{array}{l}\text { service, performance, } \\
\text { hospitality, management, } \\
\text { quality, managers, strategy, } \\
\text { employees, experience, } \\
\text { tourism, satisfaction, market }\end{array}$ & $104(24.94 \%)$ \\
\hline 4 & $\begin{array}{l}\text { consumer, brand, intention, } \\
\text { behavior, hospitality, } \\
\text { social_media, strategy, } \\
\text { perceived, loyalty, tourism, } \\
\text { online_review, trust, service, } \\
\text { communication }\end{array}$ & $94(22.54 \%)$ \\
\hline
\end{tabular}

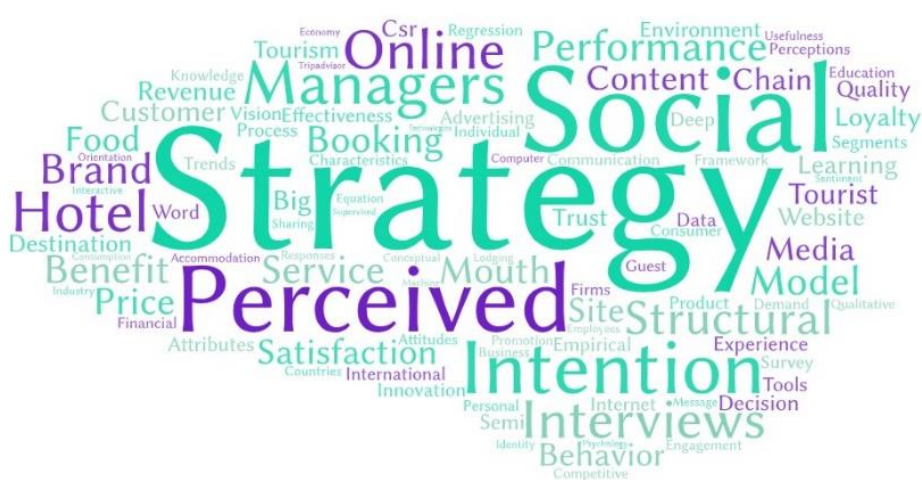

Figure 5. Word cloud for cluster 2.

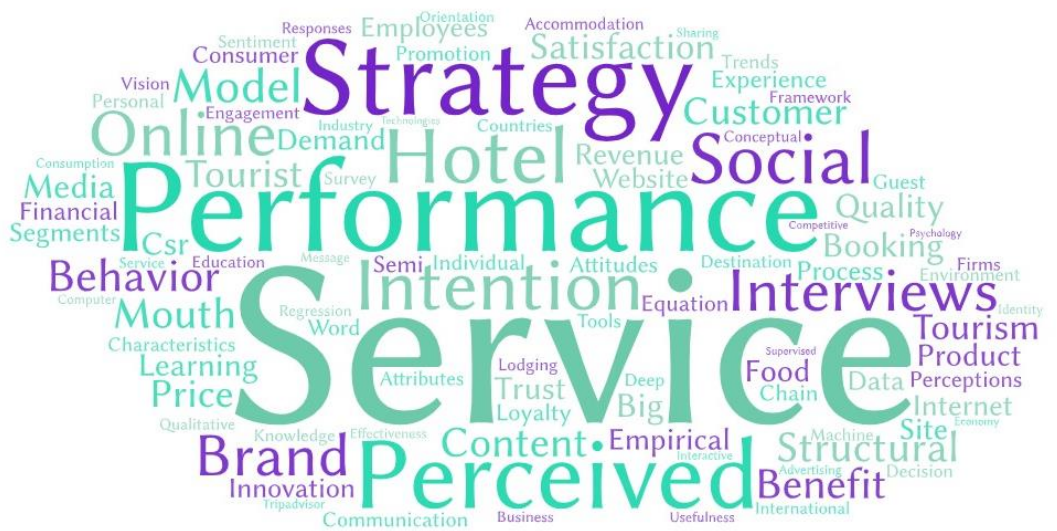

Figure 6. Word cloud for cluster 3. 


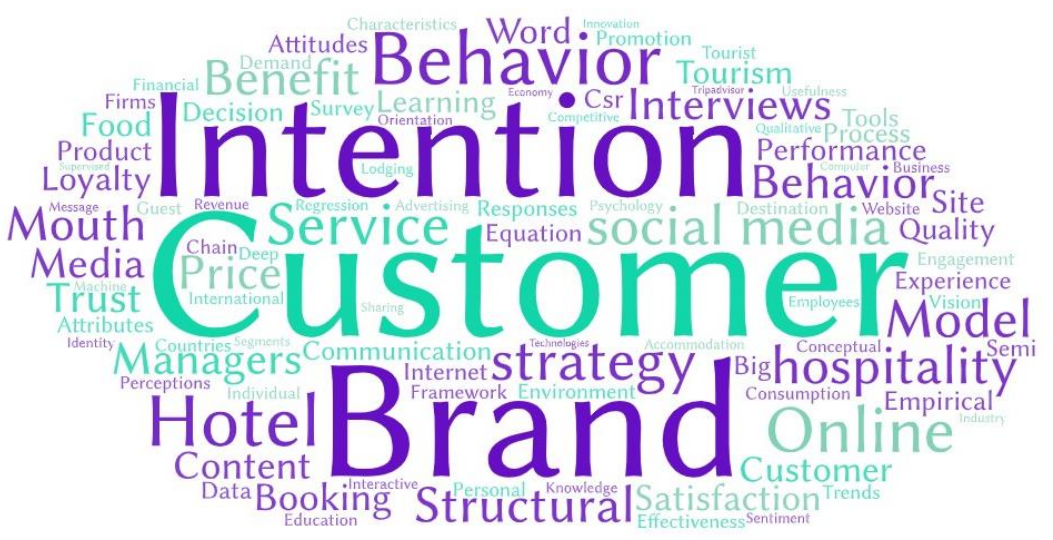

Figure 7. Word cloud for cluster 4 .

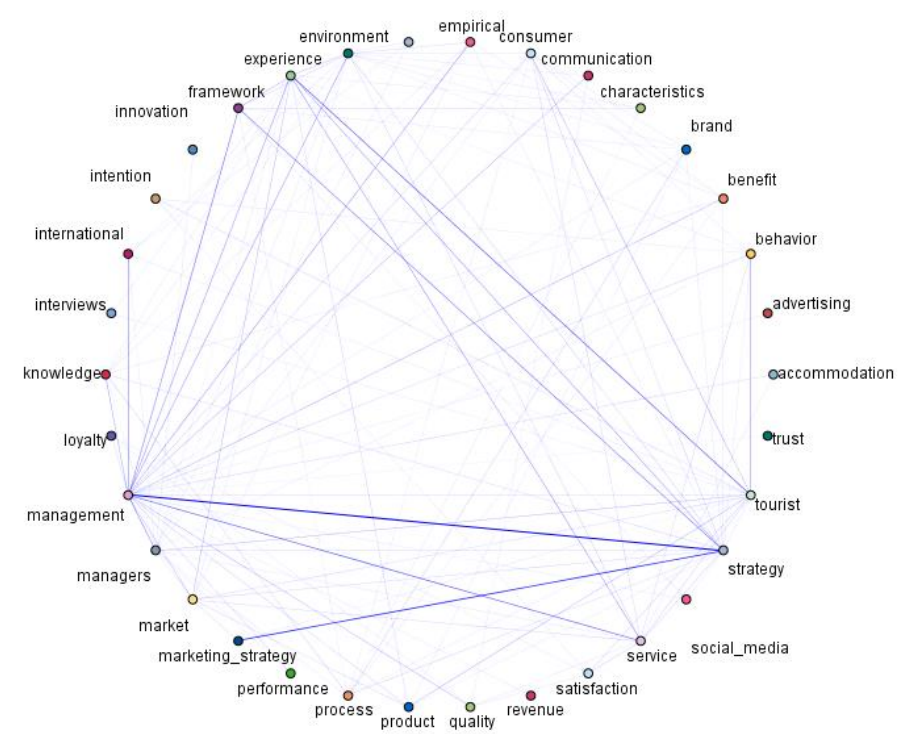

Figure 8. Web chart for cluster 1.

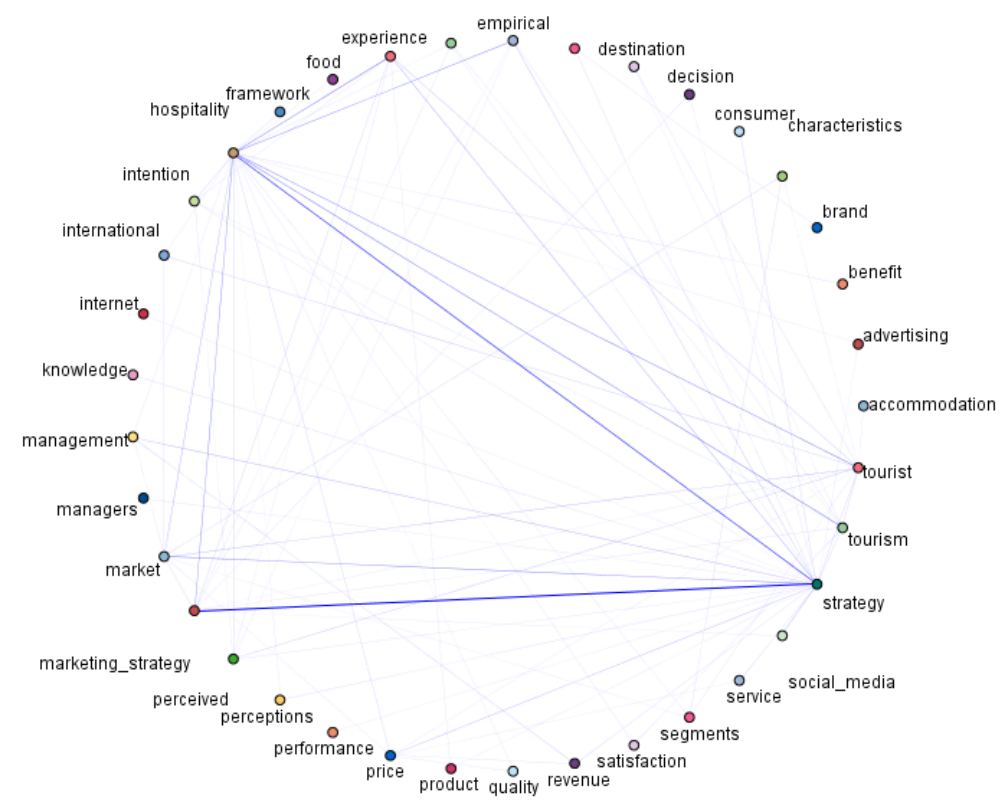

Figure 9. Web chart for cluster 2. 


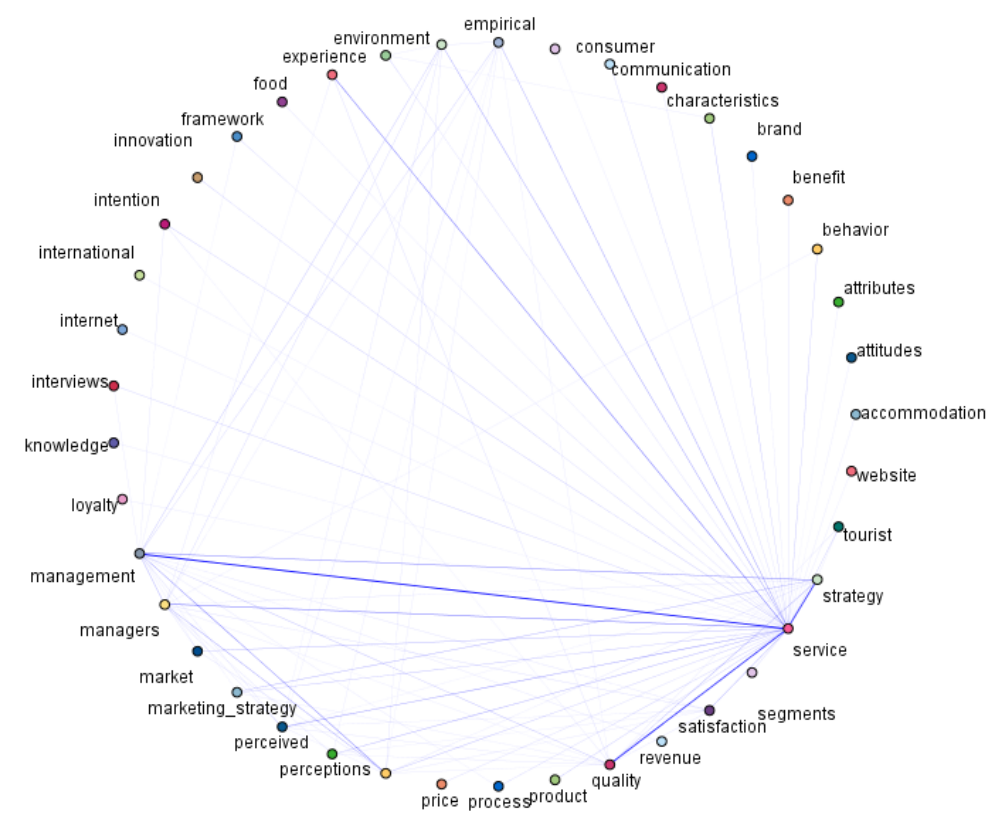

Figure 10. Web chart for cluster 3.

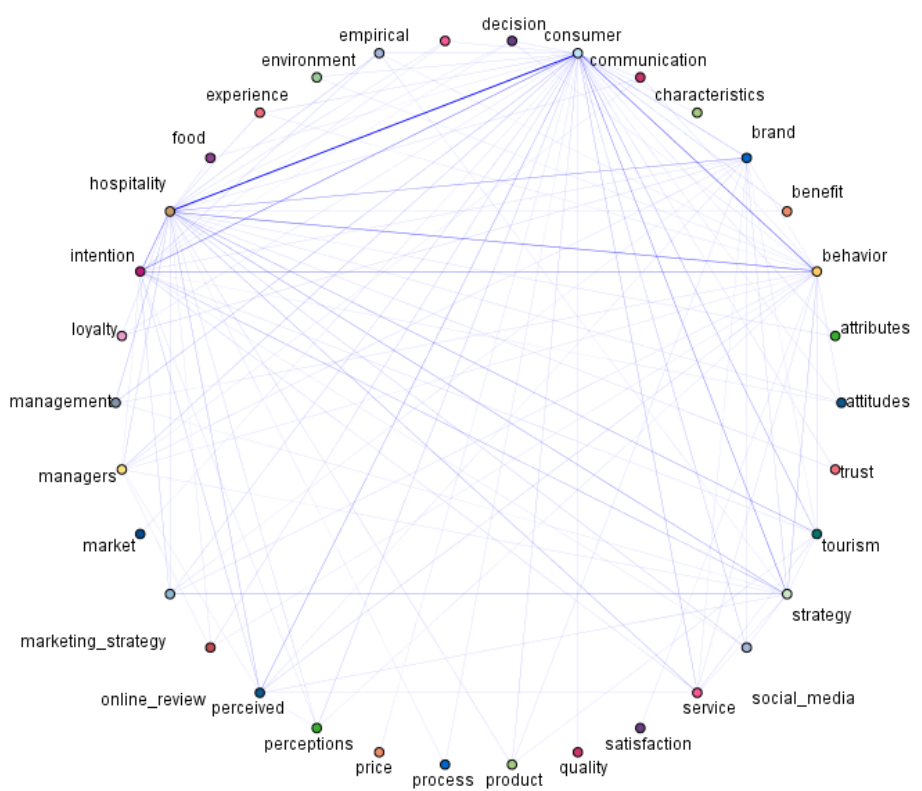

Figure 11. Web chart for cluster 4.

After clustering, we performed the association rule algorithm to explore the associations between the words in each cluster. As shown in Table 3, we selected the rules with $100 \%$ confidence in each cluster. In cluster 1, hospitality was regarded as the consequence variable, and the words related to this term with $100 \%$ confidence included "brand", "framework", "process", "tourism", and "strategy". In cluster 2, strategy served as the consequence variable, and the only term associated with this term with $100 \%$ confidence was "market strategy". In cluster 3, service was the consequence variable, and the words associated with this term with $100 \%$ confidence were "product", "behavior", "tourist", "experience", "quality", "hospitality". In cluster 4, consumers was the consequence variable, and the terms related to this term with 100\% confidence were "online review", "benefit", and "innovation". 
Table 3. The results of the association rule.

\begin{tabular}{|c|c|c|c|c|}
\hline Cluster & Consequent & Antecedent & Support & Confidence \\
\hline \multirow{5}{*}{ Cluster 1} & \multirow{5}{*}{ hospitality } & brand & 11.34 & 100 \\
\hline & & framework & 13.4 & 100 \\
\hline & & process, tourism & 17.53 & 100 \\
\hline & & framework, tourism & 11.34 & 100 \\
\hline & & strategy, management & 12.37 & 100 \\
\hline Cluster 2 & strategy & marketing strategy & 24.59 & 100 \\
\hline \multirow{6}{*}{ Cluster 3} & \multirow{6}{*}{ service } & product & 10.58 & 100 \\
\hline & & behavior & 10.58 & 100 \\
\hline & & tourist & 10.58 & 100 \\
\hline & & experience & 18.27 & 100 \\
\hline & & tourism, quality & 10.58 & 100 \\
\hline & & experience, hospitality & 11.54 & 100 \\
\hline \multirow{4}{*}{ Cluster 4} & \multirow{4}{*}{ consumer } & online review & 10.64 & 100 \\
\hline & & benefit & 11.7 & 100 \\
\hline & & online review, innovation & 10.64 & 100 \\
\hline & & benefit, innovation & 11.7 & 100 \\
\hline
\end{tabular}

\section{Discussion}

This study reviewed the hotel marketing management research published in 27 hospitality journals from 2010 to 2020. The results indicate that 417 published articles were related to hospitality marketing.

\subsection{Theoretical Contributions}

Firstly, this research is the first attempt to review the articles on the hotel industry. In the past, there have been retrospective articles on the hospitality industry; however, their scope included restaurants, catering, and other related industries. In this research, only relevant literature on marketing topics in the hotel industry was reviewed, and the results better describe the trend of marketing research for the hotel industry than other reviews and can serve as a better reference for this industry. This study found that hotel marketing management research from the past 10 years can be divided into four major categories: marketing framework, marketing strategy, service, and consumer behavior. Articles on marketing framework discussed hospitality marketing [4], consumer value [44], and social media [45]. Future researchers who want to write retrospective documents can refer to our work to find a specific group of articles. If hoteliers want to learn more about a single marketing topic, they can refer to related articles. In marketing strategy, social media marketing and sustainable marketing have been common marketing strategies in recent years. For example, Hsu [46] used Facebook to develop digital marketing strategies for Taiwanese restaurants, Leun et al. [42] used message theory to explore social media marketing among hotels, Xiong and $\mathrm{Hu}$ [47] examined viral marketing and discussed discount strategies in restaurants, and Sellers-Rubio and Calderón-Martínez [48] discussed the relationship between brand strategy and advertising expenditure. Hussain et al. [49] found that sustainable marketing assets have positive and significant effects on market performance. In addition, service is still the key to successful hotel marketing. For example, Chang [50] discussed the relationship between servicescape and customer behavioral intentions. Choi et al. [51] used the stressor-strain-outcome model as the basis to verify the relationship between emotional exhaustion, customer orientation, and service recovery performance. Ma et al. [52] found that hotel service engagement significantly informed subsequent product purchases. Understanding consumer behavior through big data has also been a research trend in recent years. Kim et al. [53] explored the gender and expertise differences in consumers' motivations for reading hotel online reviews. Li et al. [54] investigated the effectiveness of meta discourse and interpretation in dealing with negative reviews using two important linguistic features. Mariani and Predvoditel- 
eva [55] examined the impact of cultural traits and perceived experiences in the context of Russian hotels' online review ratings. Second, most of the previous review articles only focused on specific marketing issues-for example, smartphones in tourism and hospitality marketing [56], personality [57], sustainability strategies [58], and brand management [59]. This research not only focused a specific topic but also addressed the entirety of hotel marketing management. Through such a comprehensive review, we can better understand the overall picture and evolution of hotel marketing. Third, the previous review studies on hospitality marketing were conducted a decade ago [5]. The time period for this study, namely, between 2010 and 2020, could fill the gap in the literature regarding this decade. Finally, the previous retrospective articles on tourism and hospitality mostly employed bibliometrics [5,59]. This research is the first to adopt text mining to review articles. The advantage of using text mining is that data can be more comprehensively collected and analyzed. Moreover, due to the use of word segmentation, additional details can be found in the examined research.

\subsection{Practical Contributions}

This research provides some practical implications for hotel operators. First, more and more studies are being conducted on the application of big data in marketing management, especially the monitoring of social media and the analysis of online reviews through text mining. By conducting text mining, hotel operators can discover new market segments [60], implement membership marketing [61], conduct word-of-mouth marketing [62], enhance customer satisfaction [63], and increase purchase intention [63]. Although big data analysis tools have been widely used in other industries, the use of big data by hotel operators to support marketing decisions still needs to be strengthened. Furthermore, hoteliers can increase their customer value by creating unique experiences. Lahouel and Montargot [26] adopted strategic experiential modules and service encounters to discuss how luxury hotels can provide children with a memorable experience. Lee et al. [64] used big data and business intelligence technology to study the impact of customers' multi-sensory service experience on customer satisfaction through cognitive effort and emotional evaluation. Finally, since consumers are gradually shifting their information sources from mass media to social media and online communities [10], hoteliers can use social media to enhance sustainable marketing [65].

\subsection{Limitations and Future Research}

The research limitations of this study are as follows. Some influential research on hotel marketing may only be written in books or published in non-SSCI index journals, and conference articles are not included in this research database. Furthermore, this research refers to articles that include "marketing", "restaurant", and "hospitality" in the abstract. This omitted the study of closely related constructions or constructions that serve as the basis of marketing research. Moreover, we did not search for keywords related to management, business, or other fields. Using these keywords to search for management and business journals and build a database, one can collect more research on marketing management applications in different industries, but this research would not necessarily have been applicable to the hotel industry; thus, this article only focused on articles in the hotel field. Future empirical research can focus on marketing at different levels of an organization. Research on a specific level provides the ability to draw conclusions in a specific context, as well as an explanation of the actions and practices of roles and responsibilities at a specific organizational level. In this context, existing marketing theories play a critical role because they provide a valuable starting point for understanding the specific level of hotel marketing. We believe that we should explore the value of existing theories that represent hotel marketing on a multi-perspective and cross-functional level. This would enable the hotel marketing management field to overcome overspecialization and fragmentation and establish a good theoretical foundation, and continue to open up innovation and develop constructive ideas. 


\section{Conclusions}

This study reviewed the literature on marketing management in the hotel industry from 2010 to 2020 in an attempt to summarize research trends and suggest directions for future research. In contrast to the bibliometric approach often used in the past, this study performed text mining and an analysis of 417 papers, and we performed the association rule algorithm to explore the associations between the words in each cluster. Through cluster analysis, we found that marketing management research can be divided into four groups, namely, literature regarding marketing reviews and frameworks, marketing strategies, services, and customers. By using the association rule algorithm, we further explored the associations between the words in each cluster. Finally, based on the results of this study, we suggested directions for future scholarly marketing research.

Author Contributions: Conceptualization, J.-S.H., C.-H.L., S.-F.C., T.-Y.Y. and D.-C.H.; methodology, T.-Y.Y., C.-H.L. and D.-C.H.; software, T.-Y.Y. and D.-C.H.; validation, J.-S.H., C.-H.L., S.-F.C., T.-Y.Y. and D.-C.H.; formal analysis, T.-Y.Y. and D.-C.H.; investigation, J.-S.H., T.-Y.Y. and D.-C.H.; resources, J.-S.H., C.-H.L., S.-F.C., T.-Y.Y. and D.-C.H.; data curation, D.-C.H.; writing-original draft preparation, D.-C.H.; writing-review and editing, J.-S.H. and D.-C.H.; visualization, D.-C.H.; supervision, J.-S.H.; project administration, J.-S.H.; funding acquisition, J.-S.H. All authors have read and agreed to the published version of the manuscript.

Funding: The authors would like to thank anonymous reviewers for useful suggestions and the Ministry of Science and Technology of Taiwan for financial support [Grant number: MOST 109-2511H-158-004]

Institutional Review Board Statement: Not applicable.

Informed Consent Statement: Not applicable.

Data Availability Statement: Not applicable.

Conflicts of Interest: The authors declare no conflict of interest.

\section{References}

1. Bowen, J.; Sparks, B.A. Hospitality marketing research: A content analysis and implications for future research. Int. J. Hosp. Manag. 1998, 17, 125-144. [CrossRef]

2. Oh, H.; Kim, B.-Y.; Shin, J.-H. Hospitality and tourism marketing: Recent developments in research and future directions. Int. J. Hosp. Manag. 2004, 23, 425-447. [CrossRef]

3. Svensson, G.; Svaeri, S.; Einarsen, K. 'Empirical characteristics' of scholarly journals in hospitality and tourism research: An assessment. Int. J. Hosp. Manag. 2009, 28, 479-483. [CrossRef]

4. Dev, C.S.; Buschman, J.D.; Bowen, J.T. Hospitality Marketing: A Retrospective Analysis (1960-2010) and Predictions (2010-2020). Cornell Hosp. Q. 2010, 51, 459-469. [CrossRef]

5. Yoo, M.; Lee, S.; Bai, B. Hospitality marketing research from 2000 to 2009: Topics, methods, and trends. Int. J. Contemp. Hosp. Manag. 2011, 23, 517-532. [CrossRef]

6. Yao, B.; Qiu, R.T.; Fan, D.; Liu, A.; Buhalis, D. Standing out from the crowd-An exploration of signal attributes of Airbnb listings. Int. J. Contemp. Hosp. Manag. 2019, 31, 4520-4542. [CrossRef]

7. Nave, M.; Rita, P.; Guerreiro, J. A decision support system framework to track consumer sentiments in social media. J. Hosp. Mark. Manag. 2018, 27, 693-710. [CrossRef]

8. Asdecker, B. Travel-Related Influencer Content on Instagram: How Social Media Fuels Wanderlust and How to Mitigate the Effect. Sustainability 2022, 14, 855. [CrossRef]

9. Chatterjee, S.; Chaudhuri, R.; Sakka, G.; Grandhi, B.; Galati, A.; Siachou, E.; Vrontis, D. Adoption of Social Media Marketing for Sustainable Business Growth of SMEs in Emerging Economies: The Moderating Role of Leadership Support. Sustainability 2021, 13, 12134. [CrossRef]

10. Lou, C.; Yuan, S. Influencer Marketing: How Message Value and Credibility Affect Consumer Trust of Branded Content on Social Media. J. Interact. Advert. 2019, 19, 58-73. [CrossRef]

11. Khalil, S.; Ismail, A.; Ghalwash, S. The Rise of Sustainable Consumerism: Evidence from the Egyptian Generation Z. Sustainability 2021, 13, 13804. [CrossRef]

12. Tanveer, M.; Ahmad, A.-R.; Mahmood, H.; Haq, I. Role of Ethical Marketing in Driving Consumer Brand Relationships and Brand Loyalty: A Sustainable Marketing Approach. Sustainability 2021, 13, 6839. [CrossRef]

13. Biesenthal, C.; Wilden, R. Multi-level project governance: Trends and opportunities. Int. J. Proj. Manag. 2014, 32, 1291-1308. [CrossRef] 
14. Riffe, D. Analyzing Media Messages: Using Quantitative Content Analysis in Research, 2nd ed.; Lawrence Erlbaum: Mahwah, NJ, USA, 2005

15. Short, J.C.; Broberg, J.C.; Cogliser, C.C.; Brigham, K.H. Construct Validation Using Computer-Aided Text Analysis (CATA): An Illustration Using Entrepreneurial Orientation. Organ. Res. Methods 2010, 13, 320-347. [CrossRef]

16. Eisenhardt, K.M. Building Theories from Case Study Research. Acad. Manag. Rev. 1989, 14, 532-550. [CrossRef]

17. Leal, C.C.; Ferreira, A.I. Should I book another hotel? The effects of sickness and ethnicity on customer brand loyalty and positive word of mouth. Int. J. Hosp. Manag. 2020, 91, 102410. [CrossRef]

18. Gómez-Suárez, M.; Veloso, M. Brand experience and brand attachment as drivers of WOM in hospitality. Span. J. Mark. ESIC 2020, 24, 231-246. [CrossRef]

19. Serra-Cantallops, A.; Cardona, J.R.; Salvi, F. Antecedents of positive eWOM in hotels. Exploring the relative role of satisfaction, quality and positive emotional experiences. Int. J. Contemp. Hosp. Manag. 2020, 32, 3457-3477. [CrossRef]

20. Hwang, Y.; Gao, L.; Mattila, A.S. What recovery options to offer for loyalty reward program members: Dollars vs. Miles? Int. J. Hosp. Manag. 2020, 87, 102496. [CrossRef]

21. An, Q.; Ma, Y.; Du, Q.; Xiang, Z.; Fan, W. Role of user-generated photos in online hotel reviews: An analytical approach. J. Hosp. Tour. Manag. 2020, 45, 633-640. [CrossRef]

22. Domínguez-Navarro, S.; González-Rodríguez, M.R. Social Media managerial implications for budget accommodation venues: Use of Social Media platforms more effectively and efficiently. Qual. Quant. 2020, 54, 1671-1689. [CrossRef]

23. Ho, R.C.; Withanage, M.S.; Khong, K.W. Sentiment drivers of hotel customers: A hybrid approach using unstructured data from online reviews. Asia Pac. J. Bus. Adm. 2020, 12, 237-250. [CrossRef]

24. Tanford, S.; Kim, M.; Kim, E.J. Priming social media and framing cause-related marketing to promote sustainable hotel choice. J. Sustain. Tour. 2020, 28, 1762-1781. [CrossRef]

25. Liu, C.; Zhang, Y.; Zhang, J. The impact of self-congruity and virtual interactivity on online celebrity brand equity and fans' purchase intention. J. Prod. Brand Manag. 2020, 29, 783-801. [CrossRef]

26. Ben Lahouel, B.; Montargot, N. Children as customers in luxury hotels: What are Parisian hotel managers doing to create a memorable experience for children? Int. J. Contemp. Hosp. Manag. 2020, 32, 1813-1835. [CrossRef]

27. Slevitch, L.; Chandrasekera, T.; Sealy, M.D. Comparison of Virtual Reality Visualizations with Traditional Visualizations in Hotel Settings. J. Hosp. Tour. Res. 2020, 46, 212-237. [CrossRef]

28. Sánchez-Fernández, R.; Gallarza, M.G.; Arteaga, F. Adding dynamicity to consumer value dimensions: An exploratory approach to intrinsic values and value outcomes in the hotel industry. Int. J. Contemp. Hosp. Manag. 2020, 32, 853-870. [CrossRef]

29. Torrres, E.N.; Zhang, T.; Ronzoni, G. Measuring delightful customer experiences: The validation and testing of a customer delight scale along with its antecedents and effects. Int. J. Hosp. Manag. 2019, 87, 102380. [CrossRef]

30. George, G.; Haas, M.R.; Pentland, A. Big Data and Management. Acad. Manag. J. 2014, 57, 321-326. [CrossRef]

31. Ginsberg, J.; Mohebbi, M.H.; Patel, R.S.; Brammer, L.; Smolinski, M.S.; Brilliant, L. Detecting influenza epidemics using search engine query data. Nature 2009, 457, 1012-1014. [CrossRef]

32. Boyd, D.; Crawford, K. Critical questions for big data. Inf. Commun. Soc. 2012, 15, 662-679. [CrossRef]

33. Aiden, E.; Michel, J.-B. Uncharted: Big Data as a Lens on Human Culture; Penguin: London, UK, 2014.

34. Okoli, C.; Schabram, K. A Guide to Conducting a Systematic Literature Review of Information Systems Research; Concordia University: Montreal, QC, Canada, 2010.

35. Tranfield, D.; Denyer, D.; Smart, P. Towards a Methodology for Developing Evidence-Informed Management Knowledge by Means of Systematic Review. Br. J. Manag. 2003, 14, 207-222. [CrossRef]

36. Snyder, H. Literature review as a research methodology: An overview and guidelines. J. Bus. Res. 2019, 104, 333-339. [CrossRef]

37. Raddats, C.; Kowalkowski, C.; Benedettini, O.; Burton, J.; Gebauer, H. Servitization: A contemporary thematic review of four major research streams. Ind. Mark. Manag. 2019, 83, 207-223. [CrossRef]

38. Krippendorff, K. Reliability in Content Analysis. Hum. Commun. Res. 2004, 30, 411-433. [CrossRef]

39. Agrawal, R.; Imieliński, T.; Swami, A. Mining association rules between sets of items in large databases. In Proceedings of the ACM SIGMOD International Conference on Management of Data, Washington, DC, USA, 25-28 May 1993; pp. $207-216$.

40. Wang, Y.-F.; Chuang, Y.-L.; Hsu, M.-H.; Keh, H.-C. A personalized recommender system for the cosmetic business. Expert Syst. Appl. 2004, 26, 427-434. [CrossRef]

41. Aizawa, A. An information-theoretic perspective of $\mathrm{tf}-\mathrm{idf}$ measures. Inf. Process. Manag. 2003, 39, 45-65. [CrossRef]

42. Leung, X.Y.; Bai, B.; Erdem, M. Hotel social media marketing: A study on message strategy and its effectiveness. J. Hosp. Tour. Technol. 2017, 8, 239-255. [CrossRef]

43. Hung, C.-L. Online positioning through website service quality: A case of star-rated hotels in Taiwan. J. Hosp. Tour. Manag. 2017, 31, 181-188. [CrossRef]

44. Gallarza, M.G.; Gil-Saura, I. Consumer value in tourism: A perspective article. Tour. Rev. 2020, 75, 41-44. [CrossRef]

45. Leung, X.Y.; Sun, J.; Bai, B. Thematic framework of social media research: State of the art. Tour. Rev. 2019, 74, 517-531. [CrossRef]

46. Hsu, Y.-L. Facebook as international eMarketing strategy of Taiwan hotels. Int. J. Hosp. Manag. 2012, 31, 972-980. [CrossRef]

47. Xiong, L.; Hu, C. Harness the power of viral marketing in hotel industry: A network discount strategy. J. Hosp. Tour. Technol. 2010, 1, 234-244. [CrossRef] 
48. Sellers-Rubio, R.; Calderón-Martínez, A. Brand strategy scope and advertising spending: The more the better? Tour. Econ. 2021, 27, 70-85. [CrossRef]

49. Hussain, I.; Mu, S.; Mohiuddin, M.; Danish, R.Q.; Sair, S.A. Effects of Sustainable Brand Equity and Marketing Innovation on Market Performance in Hospitality Industry: Mediating Effects of Sustainable Competitive Advantage. Sustainability 2020, 12, 2939. [CrossRef]

50. Chang, K.-C. Effect of servicescape on customer behavioral intentions: Moderating roles of service climate and employee engagement. Int. J. Hosp. Manag. 2016, 53, 116-128. [CrossRef]

51. Choi, C.H.; Kim, T.; Lee, G.; Lee, S.K. Testing the stressor-strain-outcome model of customer-related social stressors in predicting emotional exhaustion, customer orientation and service recovery performance. Int. J. Hosp. Manag. 2014, 36, 272-285. [CrossRef]

52. Ma, S.; Zhang, C.; Wang, Y. From service engagement to product purchase: Cross-buying behavior in hospitality contexts. Int. J. Contemp. Hosp. Manag. 2020, 32, 2325-2343. [CrossRef]

53. Kim, E.E.K.; Mattila, A.S.; Baloglu, S. Effects of Gender and Expertise on Consumers' Motivation to Read Online Hotel Reviews. Cornell Hosp. Q. 2011, 52, 399-406. [CrossRef]

54. Li, C.; Cui, G.; He, Y. The role of explanations and metadiscourse in management responses to anger-reviews versus anxietyreviews: The mediation of sense-making. Int. J. Hosp. Manag. 2020, 89, 102560. [CrossRef]

55. Mariani, M.M.; Predvoditeleva, M. How do online reviewers' cultural traits and perceived experience influence hotel online ratings? An empirical analysis of the Muscovite hotel sector. Int. J. Contemp. Hosp. Manag. 2019, 31, 4543-4573. [CrossRef]

56. Kim, H.H.; Law, C.H.R. Smartphones in Tourism and Hospitality Marketing: A Literature Review. J. Travel Tour. Mark. 2015, 32, 692-711. [CrossRef]

57. Leung, R.; Law, R.; Law, C.H.R. A Review of Personality Research in the Tourism and Hospitality Context. J. Travel Tour. Mark. 2010, 27, 439-459. [CrossRef]

58. Aragon-Correa, J.A.; Martin-Tapia, I.; de la Torre-Ruiz, J.M. Sustainability issues and hospitality and tourism firms' strategies: Analytical review and future directions. Int. J. Contemp. Hosp. Manag. 2015, 27, 498-522. [CrossRef]

59. King, C. Brand management-standing out from the crowd:A review and research agenda for hospitality management. Int. J. Contemp. Hosp. Manag. 2017, 29, 115-140. [CrossRef]

60. Ahani, A.; Nilashi, M.; Ibrahim, O.; Sanzogni, L.; Weaven, S. Market segmentation and travel choice prediction in Spa hotels through TripAdvisor's online reviews. Int. J. Hosp. Manag. 2019, 80, 52-77. [CrossRef]

61. Guillet, B.D.; Shi, X. Can revenue management be integrated with customer relationship management? Int. J. Contemp. Hosp. Manag. 2019, 31, 978-997. [CrossRef]

62. González-Rodríguez, R.; Martínez-Torres, R.; Toral, S. Post-visit and pre-visit tourist destination image through eWOM sentiment analysis and perceived helpfulness. Int. J. Contemp. Hosp. Manag. 2016, 28, 2609-2627. [CrossRef]

63. Kim, W.-H.; Cho, J.-L.; Kim, K.-S. The relationships of wine promotion, customer satisfaction, and behavioral intention: The moderating roles of customers' gender and age. J. Hosp. Tour. Manag. 2019, 39, 212-218. [CrossRef]

64. Lee, M.; Lee, S.; Koh, Y. Multisensory experience for enhancing hotel guest experience: Empirical evidence from big data analytics. Int. J. Contemp. Hosp. Manag. 2019, 31, 4313-4337. [CrossRef]

65. Guijarro, E.; Santadreu-Mascarell, C.; Blasco-Gallego, B.; Canós-Darós, L.; Babiloni, E. On the Identification of the Key Factors for a Successful Use of Twitter as a Medium from a Social Marketing Perspective. Sustainability 2021, 13, 6696. [CrossRef] 